\title{
HUBUNGAN ANTARA DAYA KETAHANMALANGAN DAN MINAT BELAJAR DENGAN HASIL BELAJAR MATEMATIKA SISWA
}

\author{
Nurul Fadhilah ${ }^{1}$, Ndara Tanggu Renda ${ }^{2}$, I Nyoman Laba Jayanta ${ }^{3}$ \\ Universitas Pendidikan Ganesha
}

\begin{abstract}
This study aims to determine the relationship between: 1) the power of disability with mathematics learning outcomes, 2) interest in learning with mathematics learning outcomes, and 3) jointly between the power of resistance and interest in learning with students' mathematics learning outcomes. This type of research is ex post facto research. The population in this study were grade V students in Cluster XII of Buleleng District, Buleleng Regency 2018/2019 Academic Year totaling 220 people. In this study using proportional random sampling technique with a sample size of 140 people. Data collection methods used were questionnaire method and document recording. The data analysis technique used is descriptive analysis, simple regression analysis, and multiple regression analysis. The results showed that there was a positive and significant relationship between the power of resistance and the learning outcomes of mathematics, the interest in learning with the results of mathematics learning and together between the power of discomfort and interest in learning with the results of learning mathematics
\end{abstract}

Keyword: resilience, learning outcomes, interest in learning

\begin{abstract}
Abstrak: Penelitian ini bertujuan untuk mengetahui hubungan antara: 1) daya ketahanmalangan dengan hasil belajar matematika, 2) minat belajar dengan khasil belajar matematika, dan 3) secara bersama-sama antara daya ketahanmalangan dan minat belajar dengan hasil belajar matematika siswa. Jenis penelitian ini adalah penelitian ex post facto. Populasi pada penelitian ini adalah siswa kelas V di Gugus XII Kecamatan Buleleng Kabupaten Buleleng Tahun Pelajaran 2018/2019 yang berjumlah 220 orang. Pada penelitian ini menggunakan teknik proporsional random sampling dengan jumlah sampel 140 orang. Metode pengumpulan data yang digunakan yaitu metode kuesioner dan pencatatan dokumen. Teknik analisis data yang digunakan adalah analisis deskriptif, analisis regresi sederhana, dan analisis regresi ganda. Hasil yang didapat menunjukkan bahwa terdapat hubungan yang positif dan signifikan antara daya ketahanmalangan dengan hasil belajar matematika, minat belajar dengan hasil belajar matematika serta secara bersama-sama antara daya ketahnmalangan dan minat belajar dengan hasil beajar matematika
\end{abstract}

Kata Kunci: daya ketahanmalangan, hasil belajar, minat belajar.

\section{PENDAHULUAN}

Pendidikan merupakan hal yang sangat penting bagi kehidupan manusia karena dengan menempuh pendidikan dapat menambah pengetahuan, memiliki intelektual, dan meningkatkan sumber daya manusia. Kualitas sumber daya manusia dapat menjadi tolak ukur kemajuan di bidang pendidikan. Bertambahnya ilmu pengetahuan dan pengalaman-pengalaman dalam mengikuti pendidikan berakibat pada terbentuknya pola pikir dalam kemampuan menganalisa dan daya imajinasi.

Guru sebagai tenaga pendidik mempunyai peran yang sangat penting dalam membentuk karakter siswa, mengembangkan keterampilan yang dimiliki siswa, dan mengembangkan ilmu

'Prodi PGSD FIP Undiksha, Email: fadhilahn577国gmail.com

${ }^{2}$ Prodi PGSD FIP Undiksha, Email: ndaratanggu.renda

3Prodi PGSD FIP Undiksha, Email: laba.jayanta国undiksha.ac.id 
pengetahuan dengan baik ketika dalam pembelajaran. sehingga belajar merupakan hal yang utama dalam memperoleh pengetahuan dan pengalaman melalui proses interaksi di dalam kelas.

Berdasarkan pada Peraturan Menteri Pendidikan Nasional Republik Indonesia Nomor 22 Tahun 2006 menyebutkan kurikulum SD/MI memuat 8 mata pelajaran, muatan lokal, dan pengembangan diri. Adapun salah satu mata pelajaran yang termuat dalam 8 mata pelajaran tersebut adalah matematika. Tujuan mata pelajaran matematika yaitu : 1) dapat mengenal, menyikapi dan mengapresiasi ilmu pengetahuan dan teknologi agar siswa mampu memecahkan permasalahan dalam kehidupan sehari-hari, 2) dapat berpikir dan berperilaku ilmiah dengan kritis agar ketika dihadapkan pada suatu permasalahan siswa mampu untuk berpikir lebih kreatif dan menyelesaikan dengan mandiri. Pada kenyataannya tujuan mata pelajaran matematika belum tercapai secara maksimal. Banyak siswa yang mengeluh karena mata pelajaran matematika sulit untuk dipelajari dan banyak tugas yang diberikan. Hal ini guru harus menciptakan pembelajaran yang bermakna dan menarik bagi siswa. Jika guru sudah berhasil menciptakan pembelajaran yang bermakna dan menarik bagi siswa, maka akan berpengaruh pada hasil belajar siswa. Hakikat hasil belajar pada umumnya merupakan perubahan tingkah laku yang mencakup ranah kognitif, afektif, dan psikomotor. Hal tersebut senada dengan pendapat Susanto (2013) hasil belajar adalah perubahanperubahan yang terjadi pada diri siswa, baik yang menyangkut aspek kognitif, afektif, dan psikomotor sebagai hasil dari kegiatan belajar. Hasil belajar merupakan perubahan tingkah laku yang terjadi pada siswa mencakup aspek kognitif, afektif, dan psikomotor.

Salah satu mata pelajaran yang kurang dikuasai oleh siswa di sekolah dasar yaitu matematika. Terdapat siswa yang tidak menyukai mata pelajaran matematika karena banyak rumus-rumus yang perlu dihafalkan. Jika hal ini terus - menerus terjadi, maka hal ini akan berpengaruh pada kompetensi pengetahuan matematika. Menurut Yanti (2017) matematika merupakan salah satu bidang ilmu yang sangat bermanfaat dalam kehidupan seharihari. Sebagai ilmu pasti yang selalu diaplikasikan dalam kehidupan sehari-hari, matematika memang menempati posisi yang khusus di dalam pelajaran. Mulai dari tingkat dasar hingga tingkat pendidikan menengah atas, pelajaran matematika selalu dijadikan materi dalam ujian sekolah dan ujian nasional.

Menurut Amir \& Raisnawati (dalam Nurkholis dan Alfiani, 2018) pembelajaran matematika adalah suatu proses belajar mengajar yang dibangun oleh guru untuk mengembangkan kreatifitas berpikir siswa yang dapat meningkatkan kemampuan berpikir siswa, serta dapat meningkatkan kemampuan mengkonstruksi pengetahuan baru sebagai upaya meningkatkan penguasaan yang baik terhadap matematika. Sehingga dapat disimpulkan dari pemaparan diatas bahwa hasil belajar matematika merupakan perubahan tingkah laku yang terjadi pada siswa berkaitan dengan aspek kognitif, afektif, dan psikomotor mengenai pelajaran matematika yang dapat digunakan untuk menyelesaikan permasalahan dalam kehidupan sehari-hari.Hal ini dapat dilihat pada saat melakukan wawancara, observasi, dan pencatatan dokumentasi di Gugus XII Kecamatan Buleleng Kabupaten Buleleng. Adapun hasil yang diperoleh yaitu siswa kurang senang pada mata pelajaran matematika dikarenakan banyak rumus yang perlu dihafalkan dan tes yang diberikan oleh guru sulit. Hal ini mengakibatkan siswa kurang berminat untuk mengikuti pelajaran matematika. Terdapat siswa yang masih kesulitan dalam mengikuti pelajaran matematika. Pada saat siswa diberikan tes oleh guru, banyak dari mereka yang tidak mengerjakan dengan sungguh-sungguh. Ketika dihadapkan dengan tes yang sulit, mereka cenderung 
cepat menyerah atau mengerjakan dengan sembarangan. Akibatnya siswa cenderung tidak mau berusaha dan berpikir lebih keras dalam mengerjakan tes yang diberikan oleh gurunya. Pembelajaran didalam kelas siswa menunjukkan sikap yang pasif dan tidak terlalu banyak interaksi antara guru dengan siswa. Sehingga dapat dilihat bahwa siswa kurang tertarik untuk mengikuti pelajaran matematika. Adapun hasil pencatatan dokumentasi terkait nilai pengetahuan matematika semester I siswa kelas V SD Gugus XII Kecamatan Buleleng kabupaten Buleleng Tahun Pelajaran 2018/2019. Adapun hasilnya terdapat pada Tabel 1 berikut.

Tabel 1. Hasil Studi Dokumentasi Kelas V Mata Pelajaran Matematika

\begin{tabular}{lllllll}
\hline \multirow{2}{*}{ No } & \multirow{2}{*}{ Nama Sekolah } & $\begin{array}{l}\text { Jumlah } \\
\text { Siswa }\end{array}$ & \multirow{2}{*}{ KKM } & Ketuntasan & Rata-rata \\
& & & Sudah & Belum & Nilai \\
\hline 1 & SD No 1 Banyuasri & 38 & 73 & 31 & 9 & 77 \\
\hline 2 & SD No 2 Banyuasri & 37 & 73 & 26 & 11 & 75 \\
\hline 3 & SD No 3 Banyuasri & 13 & 73 & 10 & 3 & 77 \\
\hline 4 & SD No 4 Banyuasri & 36 & 72 & 9 & 27 & 72 \\
\hline 5 & SD No 5 Banyuasri & 35 & 65 & 35 & 0 & 75 \\
\hline 6 & MIT Mardlatillah & 61 & 68 & 39 & 22 & 75 \\
\hline Jumlah & $\mathbf{2 2 0}$ & & $\mathbf{1 4 8}$ & $\mathbf{7 2}$ & $\mathbf{4 5 1}$ \\
\hline Rata-rata & & & & & $\mathbf{7 5}$ \\
\hline
\end{tabular}

Berdasarkan pada Tabel 1 tersebut, dapat dilihat bahwa terdapat 148 siswa sudah mencapai KKM dan 72 orang belum mencapai KKM. Hal ini sama dengan 33\% siswa masih mengalami masalah dan kesulitan dalam pelajaran matematika. Namun dilihat dari nilai rata - rata siswa pada gugus XII Kecamatan Buleleng Kabupaten Buleleng adalah 75, maka nilai rata - rata siswa berada pada rentangan 65 - 79. Kemudian nilai rata - rata siswa dikonversikan ke dalam penilaian acuan patokan (PAP) skala lima menurut Agung (2014, hlm. 146) yang berada pada kategori sedang. Hal ini menunjukkan bahwa siswa masih mengalami masalah - masalah ketika mengikuti pelajaran matematika.

Jika diperhatikan kembali berdasarkan hasil wawancara dan observasi tersebut, siswa memiliki masalah - masalah dalam mengikuti pembelajaran. Terdapat beberapa masalah yang dihadapi oleh siswa yaitu 1) siswa sulit menyelesaikan tes yang diberikan, 2) siswa tidak bersungguh sungguh dalam mengerjakan tes, dan 3) siswa menunjukkan sikap pasif dalam pembelajaran. Sehingga tampak siswa kurang senang dalam pelajaran matematika, hal ini sangat berpengaruh pada minat siswa untuk belajar. Siswa yang tidak memiliki minat untuk belajar akan berpengaruh pada rendahnya nilai hasil belajar matematika. Jika disebabkan oleh masalah - masalah yang dihadapi anak selama mengikuti pembelajran, maka jelas siswa tersebut tidak memiliki ketahanmalangan. Berdasarkan pemaparan tersebut, antara ketahanmalangan dan minat belajar mempunyai hubungan.

Daya ketahanmalangan atau yang disebut dengan istilah Adversity Quotient merupakan faktor untuk menggabungkan antara IQ (Intelectual Quotient) dan EQ (Emotional Quotient) dalam memprediksi keberhasilan seseorang yang dicetuskan oleh Paul G. Stolz. Menurut Yoga (2016) menggambarkan hubungan antara IQ, EQ, dan AQ antara lain: 1) IQ biasanya dikaitkan dengan kecemerlangan otak. Namun, jika hanya mengandalkan kecemerlangan otak, tidak menjamin kehidupan seseorang akan mencapai puncak keberhasilan. Orang ber-IQ tinggi juga perlu memiliki EQ yang bagus sehingga memiliki kemampuan hipotesis yang tinggi, mampu mengandalkan dorongan-dorongan hati, dan lebih mampu bertahan. Adanya sinergitas antara IQ dan EQ menjadikan pribadi seseorang menjadi lebih utuh. 2) IQ berperan dalam 
memudahkan seseorang untuk berpikir logis matematis, EQ menjadi bekal bagi seseorang untuk lebih bijaksana dan terkendali. Sementara itu, AQ merupakan faktor penentu kesuksesan yang salah satu komponennya adalah ketekunan dan daya juang. Selain itu, AQ juga merupakan perpaduan antara IQ dan EQ sehingga bisa membentuk seseorang untuk lebih berdaya, produktif, dan matang dalam berbagai pertimbangan.

Daya ketahanmalangan adalah sebuah teori yang merumuskan tentang apa yang dibutuhkan untuk mencapai kesuksesan (Yoga, 2016). Sedangkan Stoltz (2004) mengatakan daya ketahanmalangan memiliki tiga bentuk gabungan dari ketiga unsur tersebut yakni pengetahuan baru, tolok ukur, dan peralatan yang praktis. Sehingga dapat disimpulkan bahwa daya ketahanmalangan adalah suatu konsep yang menjadi tolak ukur seseorang bertahan dari kesulitan dan untuk meraih kesuksesan. Jika ada orang yang memiliki daya ketahanmalangan yang tinggi, maka orang tersebut akan mampu bertahan dalam kesulitan dan mencapai kesuksesan, namun jika seseorang memiliki daya ketahanmalangan yang rendah, maka orang tersebut tidak akan mampu bertahan dalam kesulitan dan cenderung akan gagal.

Terdapat tiga kerangka dasar pembentuk daya ketahanmalangan yang dikemukakan oleh Stoltz (2004). Kerangka ini merupakan komponen yang akan membentuk sinergitas kepribadian adversitas dalam diri seseorang yaitu 1) psikologi kognitif (kemampuan manusia dalam mengatasi/mengendalikan hidup), 2) Neurofisiologi (hubungan antara belajar dan kebiasaan), dan 3) Psikoneroimunologi (Perasaan mempunyai pengaruh yang sangat besar terhadap kesehatan dan vitalitas). Menurut Stoltz (2004) daya ketahanmalangan memiliki 4 dimensi yaitu $\mathrm{CO}_{2} \mathrm{RE}$. $\mathrm{CO}_{2} \mathrm{RE}$ (control, origin and ownership, reach, endurance) untuk mengukur daya ketahanmalangan dalam diri seseorang.
Untuk mengetahui lebih dalam lagi terkait dengan daya ketahanmalangan, Stoltz (2004) memberikan istilah pendakian dan mengelompokkan tiga jenis kepribadian manusia yang bisa menggambarkan kemampuan daya ketahanmalangan yaitu 1) Quitters (orang yang memilih untuk keluar, menghindari kewajiban, mundur, dan berhenti), 2) Campers (Mereka yang pergi tidak seberapa jauh kemudian memutuskan mengakhiri pendakian karena merasa bosan dan mencari tempat bersembunyi dari situasi yang tidak bersahabat), dan 3) Climbers (orang yang seumur hidup membaktikan dirinya tanpa menghiraukan latar belakang, keuntungan, atau kerugian, nasib buruk atau nasib baik, dia terus bertahan).

Stoltz (2004) untuk dapat meningkatkan daya ketahanmalangan dengan menggunakan rangkaian LEAD yaitu: 1) Listen (guru mendengar respon siswa terhadap kesulitan), 2) Explore (mencari asal-usul kesulitan yang dihadapi siswa), 3) Analyze (mengubah pola pikir siswa yang negatif menjadi pola pikir yang positif), dan 3) Do (guru memotivasi siswa untuk melakukan sesuatu agar dapat menyelesaikan masalahnya). Ada empat langkah sederhana yang terlibat dalam penilaian dan mempertanyakan respons terhadap kesulitan serta meningkatkan daya ketahanmalangan. Tidak hanya daya ketahanmalangan yang perlu guru tingkatkan agar kompetensi pengetahuan siswa meningkat, tetapi guru juga perlu meningkatkan minat belajar yang ada pada diri siswa. Menurut Gagne (dalam Dahar, 2011, hlm. 2) belajar dapat didefinisikan sebagai suatu proses dimana suatu organisasi berubah perilakunya sebagai akibat pengalaman, yaitu: 1. perubahan perilaku, 2. perilaku terbuka, 3. belajar dan pengalaman, dan 4 . belajar dan kematangan.

Minat yang tumbuh dari dalam diri seseorang ditimbulkan karena keinginan seseorang untuk melakukan sesuatu tanpa ada paksaan dari orang lain. Menurut 
Prastowo (2012) minat adalah sifat atau sikap yang memiliki kecenderungankecenderungan atau tendensi tertentu. Minat dapat merepresentasikan tindakantindakan. Minat bukan termasuk sebagai pembawaan, tetapi sifatnya bisa diusahakan, dipelajari, dan dikembangkan. Minat adalah suatu rasa lebih suka dan rasa ketertarikan pada suatu hal atau aktivitas, tanpa ada yang menyuruh menurut Slameto (2013). Minat pada dasarnya adalah penerimaan akan suatu hubungan antara diri sendiri dengan sesuatu di luar diri. Semakin kuat atau dekat hubungan tersebut, semakin besar minat. Siswa yang memiliki minat terhadap subyek tertentu cenderung untuk memberikan perhatian yang lebih besar terhdap subjek tersebut. Sehingga dapat disimpulkan bahwa minat adalah suatu rasa ketertarikan seseorang terhadap sesuatu kecenderungan tanpa ada paksaan dari siapapun.

Minat belajar pada siswa perlu ditumbuhkan agar anak lebih bersemangat dan termotivasi untuk mengikuti pelajaran. Slameto (2013) mengatakan suatu minat dapat ekspresikan melalui: menyukai suatu hal daripada hal lainnya, partisipasi dalam suatu hal, dan memberikan perhatian yang lebih besar terhadap subjek. Adapun indikator untuk mengukur minat belajar siswa yaitu perasaan senang, partisipiasi siswa, ketertarikan belajar, dan perhatian siswa. Siswa yang memiliki minat dalam belajar tidak akan menyerah dalam menghadapi kesulitan karena siswa mampu bertahan pada masalah - masalah yang dihadapinya dalam pembelajaran. Jika dilihat dari masalah - masalah yang dihadapi oleh siswa, hal ini berarti siswa tidak memiliki daya ketahanmalangan. Daya ketahanmalangan yang dimiliki oleh siswa akan berpengaruh pada minat siswa dalam belajar. Siswa yang memiliki minat belajar tinggi akan meningkatkan hasil belajar matematika siswa. oleh sebab itu, penelitian dilakukan untuk mengetahui: 1) apakah daya ketahanmalangan berpengaruh positif dan signifikan dengan kompetensi pengetahuan matematika, 2) apakah minat belajar berpengaruh positif dan signifikan dengan kompetensi pengetahuan matematika, 3) apakah daya ketahnmalangan dan minat belajar berpengaruh positif dan signifikan dengan kompetensi pengetahuan matematika.

\section{METODOLOGI PENELITIAN}

Pada penelitian ini merupakan penelitian expost facto karena tidak memanipulasi variabel dan menggali fakta yang sudah terjadi sebelumnya.

Populasi dalam penelitian ini adalah siswa kelas V dari sekolah yang terdapat pada gugus XII Kecamatan Buleleng Tahun Pelajaran 2018/2019 sebanyak 220 orang. Berdasarkan data populasi tersebut selanjutnya dilakukan penentuan sampel penelitian. Pengambilan sampel pada penelitian ini menggunakan teknik proporsional random sampling. Dari jumlah populasi sebanyak 220 orang didapatkan sampel sebanyak 140 orang dengan menggunakan rumus Issac dan Michael.

Dalam penelitian ini menggunakan tiga variabel, yaitu dua variabel bebas dan satu variabel terikat. Sebagai variabel bebasnya daya ketahanmalangan $\left(\mathrm{X}_{1}\right)$ dan minat belajar $\left(\mathrm{X}_{2}\right)$, sedangkan variabel terikatntya adalah hasil belajar matematika (Y). Adapun metode pengumpulan data pada penelitian ini yaitu : 1) observasi perilaku siswa di dalam kelas pada saat pelajaran matematika, 2) wawancara yang dilakukan dengan guru dan siswa kelas V, 3) kuesioner atau angket dengan memberikan pertanyaan yang dijawab oleh siswa dengan mengukur daya ketahanmalangan dan minat belajar, 4) pencatatan dokumen berupa nilai semester I tahun pelajaran 2018/2019 siswa kelas V di Gugus XII Kecamatan Buleleng.

Instrumen yang digunakan untuk pengumpulan data adalah kuesioner atau angket yang digunakan sebagai alat pengumpulan data yang dirancang. Dalam penelitian ini menggunakan dua kuesioner yakni daya ketahanmalangan dan minat belajar dengan setiap pernyataan terdapat 
pernyataan yang positif dan negatif. Penskoran dalam angket daya ketahanmalangan dan minat belajar menggunakan skala Likert. Responden diminta memberikan pilihan jawaban atau respon dalam skala ukur yang telah disediakan, misalnya sangat setuju (SS), setuju (S), ragu-ragu (RR), tidak Setuju (TS), dan sangat tidak setuju (STS). Adapun nilai yang didapat dari masingmasing kuesioner yaitu berdasarkan Tabel 2 di bawah ini.

Tabel 2. Skor Item Alternatif Jawaban Responden

\begin{tabular}{llll}
\hline No & Skala ukur & Positif & Negatif \\
\hline 1 & Sangat Setuju & 5 & 1 \\
\hline 2 & Setuju & 4 & 2 \\
\hline 3 & Ragu-ragu & 3 & 3 \\
\hline 4 & Tidak Setuju & 2 & 4 \\
\hline 5 & Sangat Tidak Setuju & 1 & 5 \\
\hline
\end{tabular}

Sebelum mengumpulkan data dengan menyebarkan kuesioner/angket, terlebih dahulu melakukan uji coba instrumen penelitian untuk mengetahui apakah kueisoner layak digunakan atau tidak. Hasil uji instrumen yang meliputi uji validitas dan uji reliabilitas diperoleh 30 butir butir pernyataan dari 40 pernyataan yang dinyatakan layak untuk mengukur daya ketahanmalangan dan minat belajar siswa.

Teknik analisis data yang digunakan yaitu uji prasyarat analisis dan uji hipotesis. Uji hipotesis yang digunakan dalam penelitian ini adalah analisi regresi sederhana dan analisis regresi ganda. Sebelum melakukan uji hipotesis, data penelitian harus memenuhi uji prasyarat analisis terlebih dahulu yaitu yang pertama uji normalitas. Daya ketahanmalangan $\left(\mathrm{X}_{1}\right)$ memperoleh nilai kolmogorov-smirnov $=$ $0,200>0,05$ maka dapat disimpulkan bahwa data daya ketahanmalangan berdistribusi normal. Minat belajar $\left(\mathrm{X}_{2}\right)$ memperoleh nilai kolmogorov-smirnov $=$ $0,200>0,05$ maka dapat disimpulkan bahwa data minat belajar berdistribusi normal. Hasil belajar matematika (Y) memperoleh nilai kolmogorov-smirnov $=$ $0,200>0,05$ maka dapat disimpulkan bahwa hasil belajar matematika berdistribusi normal.

Selanjutnya uji linieritas, pada daya ketahanmalangan dengan kompetensi pengetahuan matematika menunjukkan angka signifikan linierity sebesar 0,27
( $\mathrm{p}<0,05)$, sedangkan signifikansi Deviation from Linierity sebesar 0,891 ( $\mathrm{p}>0,05)$ sehingga daya ketahanmalangan dengan hasil belajar matematika memiliki hubungan yang berarti. Pada minat belajar dengan hasil belajar matematika menunjukkan angka signifikansi Linierity sebesar $\quad 0,48 \quad(\mathrm{p}<0,05), \quad$ sedangkan signifikansi Deviation from Linierity sebesar 0,859 ( $p>0,05)$ sehingga minat belajar dengan hasil belajar matematika memiliki hubungan yang berarti.

Selanjutnya uji multikolinieritas, kriteria pengujian uji multikorelinieritas adalah Jika $\mathbf{r}_{\mathbf{x} 1 \times 2}<0,800$ maka antar sesama variabel bebas dinyatakan menerima $\mathrm{H}_{0}$ atau tidak terjadi multikolinieritas. Sebaliknya jika $r_{x 1 \times 2}>0,800$ maka antar sesama variabel dinyatakan menerima $\mathrm{H}_{\mathrm{a}}$ atau teradi multikolinieritas. Berdasarkan hasil analisis uji multikolinieritas diperoleh harga $r_{x 1 \times 2} \quad 0,437<0,800$ sehingga antara sesama variabel bebas daya ketahanmalangan $\left(\mathrm{X}_{1}\right)$ dan minat belajar $\left(\mathrm{X}_{2}\right)$ tidak terjadi multikolinieritas atau menerima $\mathrm{H}_{0}$.

Selanjutnya uji autokorelasi, berdasarkan hasil analisis uji autokorelasi, diperoleh Durbin-Watson sebesar 1,868. Hasil analisis Durbin-Watson mendekati 2, sehingga dapat ditarik kesimpulan data penelitian tidak terjadi autokorelasi. Uji prasyarat yang terakhir yaitu uji heterokedastisitas. Kriteria pengujian heterokedastisitas yaitu jika pada grafik tampak titik-titik menyebar di atas dan di 
bawah sumbu Y, maka tidak terjadi heterokedastisitas. Namun jika pada grafik tampak titik-titik membentuk pola tertentu maka terjadi heterokedastisitas. Berdasarkan hasil analisis uji heterokedastisitas diperoleh hasil pada gambar 1 di bawah ini.

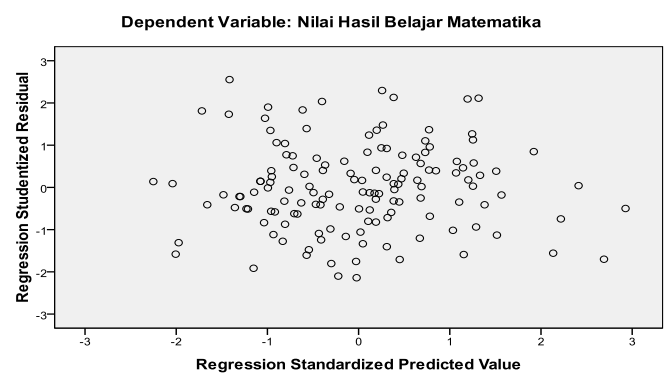

Gambar 1. Hasil Uji Heterokedastitas

Pada Gambar 1 menunjukkan diagram pencar yang terlihat titik - titik (bulatan - bulatan kecil) menyebar dan tidak membentuk pola tertentu. Hal itu menunjukkan bahwa tidak terjadi heterokedastisitas. Sehingga data bisa dilanjutkan ke analisis regresi.

\section{HASIL PENELITIAN DAN PEMBAHASAN}

Deskripsi data hasil penelitian memaparkan tentang daya ketahanmalangan $\left(\mathrm{X}_{1}\right)$ dan minat belajar $\left(\mathrm{X}_{2}\right)$ dengan hasil belajar matematika $(\mathrm{Y})$. Setelah mendapatkan deskripsi data setiap variabel, selanjutnya adalah uji hipotesis.

Pada hipotesis pertama antar variabel daya ketahanmalangan dengan hasil belajar matematika diperoleh nilai koefisien korelasi senilai 0,196 dengan signifikan sebesar 0,010 . Hal ini berarti nilai signifikannya lebih kecil dari 0,05 maka nilai korelasi tersebut signifikan. Kemudian diperoleh lagi diperoleh $F_{\text {hitung }}$ 5,521 > $F_{\text {tabel }}$ 3,06 maka dapat ditarik kesimpulan garis regresi bersifat signifikan. Sehingga $\mathrm{H}_{0}$ yang berbunyi tidak terdapat hubungan yang positif dan signifikan antara daya ketahanmalangan dengan hasil belajar matematika siswa kelas V SD di Gugus XII Kecamatan Buleleng Kabupaten Buleleng Tahun Pelajaran 2018/2019 ditolak, dan $\mathrm{H}_{\mathrm{a}}$ diterima. Adapun sumbangan koefisien determinasinya sebesar $3,8 \%$ dengan persamaan garis regresi $\mathrm{Y}=58,122+0,148$ $\mathrm{X}_{1}$. Penelitian yang dilakukan oleh Pertiwi (2018) dengan hasil bahwa rata-rata siswa yang tergolong memiliki Adversity Quotient (AQ) tinggi dapat memperoleh hasil belajar matematika yang lebih tinggi daripada siswa yang memiliki Adversity Quotient (AQ) rendah. Hal yang sama dilakukan oleh Rukmana (2016) dengan hasil terdapat hubungan yang positif dan signifikan antara Adversity Quotient dengan hasil belajar matematika siswa kelas XI SMA Negeri Model Terpadu Madani Palu.

Pada hipotesis kedua antar variabel minat belajar dengan hasil belajar matematika diperoleh nilai koefisien korelasi senilai 0,176 dengan signifikan sebesar 0,019. Hal ini berarti nilai signifikannya lebih kecil dari 0,05 maka nilai korelasi tersebut signifikan. Kemudian diperoleh lagi diperoleh $\mathrm{F}_{\text {hitung }}$ 4,375 $>\mathrm{F}_{\text {tabel }}$ 3,06 maka dapat ditarik kesimpulan garis regresi bersifat signifikan. Sehingga $\mathrm{H}_{0}$ yang berbunyi tidak terdapat hubungan yang positif dan signifikan antara minat belajar dengan hasil belajar matematika siswa kelas V SD di Gugus XII Kecamatan Buleleng Kabupaten Buleleng Tahun Pelajaran 2018/2019 ditolak, dan $\mathrm{H}_{\mathrm{a}}$ diterima. Adapun sumbangan koefisien determinasinya sebesar $3,1 \%$ dengan persamaan garis regresi $\mathrm{Y}=62,550+0,110$ $\mathrm{X}_{2}$. Hasil penelitian ini sejalan dengan penelitian yang dilakukan oleh Syahputri, dkk (2019) dengan hasil ada hubungan yang positif dan signifikan antara minat belajar dan kemampuan literasi matematis dengan hasil belajar matematika siswa kelas VII SMP Muhammadiyah 9 Yogyakarta Semester Genap Tahun Ajaran 2018/2019 yang berarti bahwa semakin tinggi minat belajar maka semakin tinggi pula hasil belajarnya. Hal yang sama dilakukan Kusumo (2016) dengan hasil penelitian terdapat hubungan antara minat belajar dengan hasil belajar siswa kelas IV SDN se-Gugus Nyi Ageng Serang 
Semarang. Hal yang sama juga dilakukan oleh Wahida (2016) dengan hasil menunjukkan hubungan yang signifikan antara minat belajar matematika dengan hasil belajar matematika kelas VIII SMP Negeri 1 Sungguminasa Kabupaten Gowa. Hal yang sama dilakukan oleh Prasetyo (2019) terdapat hubungan secara bersama antara minat dan motivasi belajar terhadap hasil belajar matematika siswa. Hal yang sama dilakukan oleh Widyastuti dkk (2018) dengan hasil ada hubungan yang positif dan signifikan antara minat belajar matematika keaktifan siswa dan fasilitas belajar di sekolah dengan prestasi belajar matematika.

Pada hipotesis ketiga antar variabel secara bersama-sama antara daya ketahanmalangan dan minat belajar dengan hasil belajar matematika diperoleh $F_{\text {hitung }}$ 3,484 > $F_{\text {tabel }}$ 3,06 maka dapat ditarik kesimpulan garis regresi bersifat signifikan. Sehingga $\mathrm{H}_{0}$ yang berbunyi tidak terdapat hubungan yang positif dan signifikan secara bersama-sama antara daya ketahanmalangan dan minat belajar dengan kompetensi pengetahuan matematika siswa kelas V SD di Gugus XII Kecamatan Buleleng Kabupaten Buleleng Tahun Pelajaran 2018/2019 ditolak, dan $\mathrm{H}_{\mathrm{a}}$ diterima. Adapun nilai koefisien kontribusi yaitu 0,220 . Jadi dapat disimpulkan bahwa $\mathrm{r}_{\text {hitung }} 0,220>\mathrm{r}_{\text {tabel }} 0,166$ maka $\mathrm{H}_{0}$ ditolak yang berarti signifikan. Adapun besar koefisien determinasinya adalah $4,8 \%$ dengan persamaan garis regresi $\mathrm{Y}=54,137$ $+0,112 X_{1}+0,070 X_{2}$. Hasil penelitian ini sejalan dengan penelitian yang dilakukan oleh Wardiana, dkk., (2014) dengan hasil bahwa Semakin tinggi AQ yang dimiliki siswa maka semakin tinggi tinggi pula ketahanmalangan yang dimiliki siswa tersebut jika mendapatkan kesulitan dalam hidupanya serta jika siswa memiliki minat belajar yang semakin tinggi dan meningkat, maka siswa tersebut tidak akan merasa puas tentang apa yang dipelajari dan akan terus belajar untuk memenuhi rasa ingin tahunya. Kemudian minat belajar siswa dapat mendorong dan memberikan motivasi kepada siswa untuk belajar lebih giat lagi. Daya ketahanmalangan menunjukkan sikap siswa untuk mengatasi segala kesulitan dan masalah yang dihadapinya, siswa diharapkan mampu untuk meningkatkan daya ketahanmalangan yang ada pada dirinya agar mampu untuk bertahan dalam keadaan sulit dan mampu bertahan pada masalah yang dihadapinya. Untuk dapat meningkatkan daya ketahanmalangan dengan menggunakan rangkaian LEAD (Listen, Explore, Analyze, dan Do). Jika telah diterapkan rangkaian LEAD tersebut, siswa yang memiliki daya ketahanmalangan yang tinggi, maka siswa tersebut cenderung dapat bertahan dalam kesulitan dan meraih kesuksesan. Hal ini berbeda jika siswa yang memiliki daya ketahanmalangan yang rendah, maka siswa tersebut cenderung tidak dapat bertahan dalam kesulitan dan mudah meraih kegagalan. Kesuksesan yang dimaksud yaitu meningkatnya hasil belajar matematika siswa.

Penelitian ini juga dilakukan penelitian tentang minat belajar siswa, didapat bahwa minat belajar memberikan pengaruh atau kontribusi sebesar 3,1\% untuk kompetensi pengetahuan matematika siswa. hasil penelitian mengungkapkan bahwa hasil $r_{\text {hitung }}$ sebesar 0,175 dan $r_{\text {tabel }}$ sebesar 0,166 yang berarti $0,175>r_{\text {tabel }}$ 0,166 , sehingga dapat disimpulkan bahwa $\mathrm{H}_{\mathrm{a}}$ yang berbunyi terdapat hubungan yang positif dan signifikan antara minat belajar dengan hasil belajar matematika siswa kelas V SD di Gugus XII Kecamatan Buleleng Kabupaten Buleleng Tahun Pelajaran 2018/2019 diterima. Minat belajar pada siswa perlu ditumbuhkan agar anak lebih bersemangat dan termotivasi untuk mengikuti pelajaran. Minat pada dasarnya adalah penerimaan akan suatu hubungan antara diri sendiri dengan sesuatu di luar diri. Semakin kuat atau dekat hubungan tersebut, semakin besar minat. Siswa yang memiliki minat terhadap subyek tertentu cenderung untuk memberikan perhatian yang lebih besar terhdap subjek tersebut. Upaya guru untuk 
meningkatkan minat pada diri siswa yaitu menumbuhkan perasaan siswa senang dalam mengikuti pelajaran matematika, dapat meningkatkan partisipasi siswa dalam pelajaran matematika, menumbuhkan ketertarikan siswa dalam belajar matematika, dan meningkatkan perhatian siswa dalam pembelajaran matematika. sehingga minat belajar siswa terhadap sesuatu yang dipelajari akan mempengaruhi hasil belajar.

Berdasarkan analisis dari kedua variabel tersebut yaitu daya ketahanmalangan dan minat belajar memberikan sumbangan sebesar 4,8\% dengan $F_{\text {hitung }}$ sebesar 3,484 dan didapat $F_{\text {tabel }}$ sebesar 3,06 yang berarti $F_{\text {hitung }} 3,484$ $>\mathrm{F}_{\text {tabel }}$ 3,06 dan $\mathrm{r}_{\text {hitung }}$ sebesar 0,220 dengan $\mathrm{r}_{\text {tabel }}$ sebesar 0,166 yang berarti $\mathrm{r}_{\text {hitung }} 0,220$ $>\mathrm{r}_{\text {tabel }} 0,166$ maka $\mathrm{H}_{\mathrm{a}}$ yang berbunyi terdapat hubungan yang positif dan signifikan secara bersama-sama antara daya ketahanmalangan dan minat belajar dengan hasil belajar matematika siswa kelas V SD di Gugus XII Kecamatan Buleleng Kabupaten Buleleng Tahun Pelajaran 2018/2019 diterima.

\section{KESIMPULAN}

Dari hasil uji hipotesis dan pembahasan dapat disimpulkan adalah pertama, terdapat hubungan signifikan antara daya ketahanmalangan $\left(\mathrm{X}_{1}\right)$ dengan hasil belajar matematika (Y) siswa kelas V di Gugus XII Kecamatan Buleleng Kabupaten Buleleng Tahun Pelajaran 2018/2019 dinyatakan diterima. Dalam penelitian ini ditemukan korelasi yang positif dan signifikan yang berarti semakin tinggi daya ketahanmalangan siswa maka semakin tinggi hasil belajar matematika siswa. Sumbangan daya ketahanmalangan yang dimiliki siswa dengan hasil belajar matematika sebesar 3,8\%. Kedua, terdapat hubungan signifikan antara minat belajar $\left(\mathrm{X}_{2}\right)$ dengan hasil belajar matematika $(\mathrm{Y})$ siswa kelas V di Gugus XII Kecamatan Buleleng Kabupaten Buleleng Tahun Pelajaran 2018/2019 dinyatakan diterima. Dalam penelitian ini ditemukan korelasi yang positif dan signifikan yang berarti semakin tinggi minat belajar siswa maka semakin tinggi hasil belajar matematika siswa. Sumbangan minat belajar yang dimiliki siswa dengan hasil belajar matematika sebesar 3,1\%. Ketiga, terdapat hubungan signifikan antara daya ketahanmalangan $\left(\mathrm{X}_{1}\right)$ dan minat belajar $\left(\mathrm{X}_{2}\right)$ dengan hasil belajar matematika $(\mathrm{Y})$ siswa kelas V di Gugus XII Kecamatan Buleleng Kabupaten Buleleng Tahun Pelajaran 2018/2019 dinyatakan diterima. Dalam penelitian ini ditemukan korelasi yang positif dan signifikan yang berarti semakin tinggi daya ketahanmalangan dan minat belajar siswa maka semakin tinggi hasil belajar matematika siswa. Sumbangan minat belajar yang dimiliki siswa dengan hasil belajar matematika sebesar $4,8 \%$.

Adapun saran yang dapat disampaikan berdasarkan hasil analisis tersebut adalah 1) Bagi siswa, disarankan untuk meningkatkan daya ketahanmalangan dan minat belajar yang dimiliki, sehingga siswa dapat menyelesaikan masalah yang dihadapi pada saat pembelajaran dan dapat meningkatkan hasil belajar matematika. 2) Bagi guru, disarankan untuk dapat membimbing, memotivasi dan mengingkatkan daya ketahanmalangan dan minat belajar siswa. hal itu dilakukan agar siswa tidak takut pada pelajaran matematika dan akan berpengaruh pada meningkatnya hasil belajar. 3) Bagi sekolah, disarankan untuk dapat mendukung dengan tersedianya sarana dan prasarana penunjang seperti media atau alat - alat peraga untuk meningkatkan daya ketahanmalangan dan minat belajar siswa. 4) Bagi penelitian lain, disarankan dengan hasil penelitian ini digunakan sebagai referensi untuk melakukan penelitian yang sejenis dan bermanfaat bagi pihak-pihak yang melakukan penelitian ini.

\section{DAFTAR PUSTAKA}

Agung, A. A. G. (2014). Buku Ajar Metodologi Penelitian Pendidikan. 
Yogyakarta: Aditya Media Publishing.

Dahar, R. W. (2011). Teori-Teori Belajar dan Pembelajaran. Jakarta: Erlangga.

Depdiknas. (2006). Peraturan Menteri Pendidikan Nasional Republik Indonesia Nomor 22 Tahun 2006 Tentang Standar Isi Untuk Satuan Pendidikan Dasar dan Menengah. 2006. Jakarta: Depdiknas.

Kusumo, S. (2016) Hubungan Antara Minat Belajar Dengan Hasil Belajar Siswa Kelas Iv Sdn SeGugus Nyi Ageng Serang Semarang. Skripsi. Universitas Negeri Semarang.

Nurkholis dan Alfiani, F. (2018). Pengaruh Kecerdasan Adversity Quotient (AQ) Terhadap Hasil Belajar Matematika Di SDN 1 Pekantingan Kecamatan Klangenan Kabupaten Cirebon. Edisi Khusus (hlm. 235242).

Pertiwi, N. L. C. (2018). Hubungan Antara Adversity Quotient (AQ) dengan Hasil Belajar Matematika Siswa Kelas V SD Gugus VI Abiansemal Tahun Ajaran 2017/2018. Skripsi (tidak diterbitkan). Jurusan Pendidikan guru Sekolah Dasar, Universitas Pendidikan Ganesha Singaraja.

Prasetyo, A. N. A. (2019). Hubungan Minat Dan Motivasi Belajar Siswa Terhadap Hasil Belajar Matematika Kelas Vii Di Mtsn 2 Surakarta. Skripsi (tidak diterbitkan). Program Studi Pendidikan Matematika. Universitas Muhammadiyah Surakarta.

Prastowo, A. (2012). Manajemen Perpustakaan Sekolah Profesional. Jogjakarta: Diva Press.

Rukmana, I. (2016). Hubungan Adversity Quotient Dengan Hasil Belajar Matematika Siswa Kelas XI Sma
Negeri Model Terpadu Madani Palu. Volume 03 Nomor 03 (hlm. $325-333)$.

Slameto. (2013). Belajar dan Faktor-faktor Yang Mempengaruhinya. Jakarta: Rineka Cipta

Stoltz, P. G. (2004). Adversity Quotient: Mengubah Hambatan Menjadi Peluang. Jakarta: PT Grasindo.

Susanto, A. (2013). Teori Belajar dan Pembelajaran di Sekolah Dasar. Jakarta: Kencana Prenadamedia Group.

Syahputri, S. N., dan Khasanah, U. (2019). Hubungan Antara Minat Belajar Dan Kemampuan Literasi Matematis Dengan Hasil Belajar Matematika. Volume 5, Nomor 1 (hlm. 331-338).

Wahida, F. (2016). Hubungan Antara Minat Belajar Matematika dengan Hasil Belajar Matematika Peserta Didik Kelas VIII SMP Negeri 1 Sungguminasa Kabupaten Gowa. Skripsi. Universitas Islam Negeri Alauddin Makassar.

Wardiana, I Pt Arya, dkk. (2014). Hubungan Antara Adversuty Quotient (AQ) dan Minat Belajar dengan Prestasi Belajar Matematika pada Siswa Kelas V SD Di Kelurahan Pedungan. Volume 2. Nomor 11.

Widyastuti, E dan Wibowo, S. A. (2018). Hubungan Antara Minat Belajar Matematika Keaktifan Siswa Dan Fasilitas Belajar Disekolah Dengan Prestasi Belajar Matematika Siswa Kelas X Smk Se-Kecamatan Umbulharjo. Prosiding Seminar Nasional Etnomatnesia. ISBN: 978602-6258-07-6. Halaman 873 - 881.

Yanti, D. (2017). Pengertian Matematika dan Sejarah Ilmu Matematika. terdapat pada halaman https://www.rumusmatematika.org/ 2017/09/pengertian-matematikadan-sejarah-ilmu.html?m=1. 
Diakses pada tanggal 22 Januari 2019.

Yoga, M. (2016). Adversity Quotient : Agar Anak Tak Gampang Menyerah. Solo: PT Tiga Serangkai Pustaka. 